\author{
Jing $\mathbf{Y u}$ \\ https://orcid.org/0000-0002-0142-6391 \\ Guangdong University of Petrochemical Technology \\ School of Economics and Management \\ Department of Marketing \\ yujing@gdupt.edu.cn \\ Azilah Kasim \\ https://orcid.org/0000-0002-2217-0989 \\ Universiti Utara Malaysia \\ School of Tourism Hospitality and Event Management \\ azilah@uum.edu.my \\ Jayashree Sreenivasan \\ https://orcid.org/0000-0001-8965-3152 \\ Malaysia Multimedia University \\ Faculty of Management \\ jayashree@mmu.edu.my \\ Hisham Dzakiria \\ https://orcid.org/0000-0001-5492-1081 \\ Universiti Utara Malaysia \\ School of Tourism Hospitality and Event Management \\ Langkawi International Tourism and Hospitality Research Center \\ hisham@uum.edu.my \\ Ahsan Ul Haq Magray \\ https://orcid.org/0000-0003-4520-1167 \\ Central Kashmir University \\ Department of Tourism \\ ahsanulhaq045@gmail.com
}

Langkawi International Tourism and Hospitality Research Center

\title{
EXPLORING DESTINATION IMAGE, FAMILIARITY, INFORMATION SEARCH BEHAVIOUR, INVOLVEMENT AND TRAVEL MOTIVATION AS INFLUENCERS OF ECOTOURISTS' DESTINATION LOYALTY'
}

\begin{abstract}
This work aims at exploring the influence of selected factors that have received little attention in the past on ecotourism destination loyalty within the context of a developing country. The factors are destination image, familiarity, information search behaviour, involvement and travel motivation. The research was conducted on ecotourists visiting Malaysia who were approached on site and assisted to complete the survey instrument. The sample size was 813, representing a response rate of $47 \%$. Hypotheses were tested using Structural Equation Model. It was found that while there are no linear relationships between the tested variables and destination loyalty, there are findings from the study that offer some managerial implications towards the industry.
\end{abstract}

Keywords: destination loyalty, destination image, familiarity, search behaviour, involvement, travel motivation.

\section{INTRODUCTION}

Understanding what could have an impact on destination and brand loyalties may be valuable in formulating destination management and marketing strategies, as well as on service delivery (Prayag, Ryan, 2012). This work attempts to examine the impact of several destination loyalty factors that past studies may have not investigated simultaneously i.e. destination image, familiarity, information search behaviour, involvement and travel motivation. The context of the study, i.e. Malaysian ecotourism, may also add to the newness 
of the findings. Its rich cultural and natural biodiversity has led Malaysia to win an award as the Best Ecotourism Destination in two consecutive years (2007-2008) at the Travel Weekly (Asia) Industry Awards. Hence, ecotourism is clearly an asset to Malaysian tourism, and understanding what contributes to loyalty to ecotourism destinations in Malaysia could help the country improve its ecotourism offering.

Attracting and retaining a target market is a challenging endeavour particularly if not much is known about the market to begin with. This is more so because invoking customer loyalty involves knowing the factors that could shape destination and brand loyalties. The same applies to ecotourism destinations in Malaysia. With so many tropical destinations globally offering ecotourism attractions, it is important that ecotourism marketing managers in Malaysia understand what will influence customers to be loyal. Promoting ecotourism as a tourism product contributes not only towards the economy (Sangpikul, 2017) but also towards destination sustainability because the nature of ecotourism encourages minimal development, low impact activities and local economy enhancement. Ecotourism also plays an educational role in sustainable development by enhancing stakeholder collaboration networks and contributing towards the educational system (Mondino, Beery, 2019). This aligns with sustainable the consumption and production that SDG11 aims for.

In the literature, the many identified antecedents of destination loyalty (such as satisfaction, perception of services, perception of value, travel motivation, destination image, destination knowledge, information search behaviour, level of involvement, number of previous trips) have been studied separately. Such an approach impedes a more comprehensive or holistic look at the issue of destination loyalty.

In addition, not much of the literature has focused on the relationships between important factors such as satisfaction, perceived quality, perceived value and destination image on destination loyalty in the context of nature-based or ecotourism. Instead, most discourse on the issue of destination loyalty has been explored only in the context of general tourism. Hence, finding guidance on targeting the potentially loyal ecotourist segment in the academic literature is difficult since not many destination loyalty studies focus on ecotourism. Hence, this work is probably one of the few that attempts to look at the influence of several destination loyalty antecedents simultaneously to see the bigger picture as not many past studies have focused on such a combination.

Hence, this study attempts to expand the research focus by extending the proposition that individual components of a destination can influence tourists' overall destination satisfaction and loyalty (see Chi, Qu, 2008; Neal, Gursoy, 2008). This approach is considered necessary because of the multi-faceted and hybrid experience offered by the tourism industry. It also aims to close gaps presented by past research that focused individually on each aspect of the service experience, and offers another perspective on destination loyalty because it studies a selected number of destination loyalty antecedents for ecotourism in the Malaysian context. The following main research question was asked: How do ecotourists' destination image, familiarity with the destination, information search behaviour, level of involvement and travel motivation influence their destination loyalty? To answer this, the remaining sections of this article are organized as follows: first, a review of relevant literature is presented; then the methodology used to gather data is explained, followed by a discussion of the findings. Finally, the article concludes by presenting possible theoretical and managerial implications of the findings.

\section{MATERIALS AND METHODS}

Ecotourism is now a concept that has grown widely (Dowling, Fennell, 2003; Hawkins, Lamoureux, 2001; WTTC, 2004). It has managed to draw the interest of many stakeholders because it has the potential ability to produce benefits for the economy and ecology of a destination (Sitar, May-Collado, Wright, 2017; Weaver, 2005; Wight, 1993). Ecotourism has also managed to attract the attention of many scholars who have attempted to give perspectives on the complexities and confusions often linked to the understanding of ecotourism (Weaver, 2005). Nonetheless, little consensus has been achieved despite the mounting numbers and time devoted to unravel the true meaning of ecotourism (see Blamey, 2001; Honey, 1999; Hvenegaard, 1994). Instead, the various interpretations of ecotourism have caused difficulties for managers and planners who want to find guidance to assist their duties (Donohoe and Needham, 2005a; Dowling and Fennell, 2003). As the debate on the true definition of ecotourism is not the focus of this study, one definition has been adopted to suit its purpose and that is the one by the International Ecotourism Society (TIES, 2006), as improved by Honey (2008), which said that ecotourism involves responsible behaviour that conserves natural resources and surrounding communities. It is an all-encompassing concept that includes aspects such as nature travel, environmental awareness, minimisation of negative impacts, direct monetary benefits to nature and culture, local empowerment, local jobs, human rights and democratic activity.

Visitors that visit ecotourism destinations are known as ecotourists. Even in the 1990s, there were already no less than five million eco-tourists recorded globally, 
most of whom were from North America, Europe and Australia (Kamauro, 1996). According to Wight (1996), eco-tourists can often be divided based on factors such as demography, background, motivation and preferences. They can also be divided based on other factors such as environmental attitudes (Sangpikul, 2020; Uysal, Jurowski, Noe, McDonald, 1994), cultural values (Blamey, Braithwaite, 1997) and benefits sought (Palacio, McCool, 1997). Jamieson (2001) contends that ecotourists are more concerned about causing distress during travel as they value different things and have different lifestyles and this may have an effect on their demand. For example, most North American eco-tourists look for cultural and educational values (Plog, 1974) whilst Singaporean eco-tourists look for business opportunities and new things (Swarbrooke, Horner, 1999).

\section{LOYALTY}

Some past researchers (such as Chen, Gursoy, 2001; Oppermann, 2000; Yoon, Uysal, 2005) have defined loyalty as tourists' propensity to choose the same destination for their future visits and their willingness to suggest it to others. Some authors refer to it as an intention to revisit or return to a destination they have visited before (Quintal, Polcynzski, 2010). Previous studies reported many factors that could influence destination loyalty including visit experience level (Chi, Qu, 2008; Neal, Gursoy, 2008), perceived destination services (Chen, Tsai, 2007; Chi, 2012; Chi, Qu, 2008; Cole, Illum, 2006) perceived destination value (Sun, $\mathrm{Chi}, \mathrm{Xu}$, 2013), destination image (Castro, Armario, Ruiz, 2007; Chen, Gursoy, 2001; Chen, Tsai, 2007; Chi, 2011; Chi, Qu, 2008), travel motivation (Yoon, Uysal, 2005), destination knowledge (Gursoy, McCleary, 2004a, 2004b; Konecnik, Gartner, 2007), information search behaviour (Chen, Gursoy 2000, 2011), involvement level (Gursoy, Gavcar, 2003; Havitz, Dimanche, 1999), and past trips to the destination (Gursoy, McCleary, 2004a, 2004b).

The studies on tourists' loyalty described above are in the context of general tourism. Within the context of ecotourism, not much discourse on the subject can be found. However, as Ezebilo (2014) has found, even in the context of ecotourism, a revisiting decision is directly linked to satisfaction on the first visit. In other words, building loyalty depends on a positive and satisfactory experience during a first visit. The author's contention is consistent with an empirical finding of Plessis, Merwe \& Saayman (2012) that shows the link between tourist satisfaction and tourist loyalty. The authors' study on visitors to South African National Parks indicate that there are five factors that could influence satisfaction in a national park setting i.e. tourism product offer, pollution, park violation, tourism impact and environmental management. Among these factors, pollution (from restaurants, litter and noise) contributes the most towards negative experience, followed by tourism impacts (the presence of alien plant species, trampling and erosion level along tourist routes) and park violations (overcrowding and speeding). They conclude that if ecotourists have a perceived positive experience, the level of ecotourist satisfaction will increase and the level of loyalty will also increase at the same time. Since ecotourists differ from regular tourists especially in the factors influencing their motivation and satisfaction (Kasim, Gursoy, Chi, Sreenivasan 2014), more empirical evidence is needed before more can be concluded about factors influencing their loyalty.

\section{DESTINATION IMAGE}

Destination image is one of the most frequently examined topics in tourism literature (Sun, $\mathrm{Chi}, \mathrm{Xu}, 2013$ ). It became a focus of tourism research in the early 1970s and attention increased in the 1990s. This momentum coincides with the realization by both academics and industry practitioners of the importance of a destination's image in its promotion. It has been a relatively wellstudied line of inquiry in the field of hospitality and tourism for more than 30 years.

Destination image is an essential factor because a good image could bring more tourists (Hsu, 2004). Crompton (1979) defined destination image as the sum of beliefs, ideas and impressions that a tourist holds of a place. These have been divided in the literature into two dimensions i.e. cognitive and affective. The cognitive component consists of beliefs and knowledge about the physical attributes of a destination, while the affective component refers to the feelings towards the attributes and the environment (Baloglu, McCleary, 1999; Hosany, Ekinci, Uysal, 2007). Destination image plays a significant role in influencing destination choice, the decision-making process and in the selection of onsite activities such as lodging, attractions and activities to participate in. A positive image enhances a tourist's decision to visit a particular destination ( $\mathrm{O}^{\prime}$ Leary, Deegan, 2005). If the tourist perceives a positive and favourable destination image in their mind then they are likely to desire to visit it (Beerli, Martin, 2004; Laws, Scott, Parfitt, 2002)

Destination image is also likely to have significant influences on post-trip assessment such as perceived value, satisfaction and future behavioural intentions (revisit intentions and recommendation to others) (Chen, Tsai, 2007; Lee, Lee, Lee, 2005). If any tourism authority can create a positive image in a tourist's mind then it is easier to be successful in a tourism business (Hankinson, 2004). Hall \& O'Sullivan (1996) propose that there are 
three essential factors that help to build a destination: word of mouth, a good image, and good governance. In terms of word of mouth recommendations, tourists are more likely to spread a positive word or story to their family, relatives and friends if their experience was satisfactory. In addition, the destination's good image, inculcated through good relations with the media in particular, can help influence potential tourists' decision making. Finally, good policies and proper implementation of those policies will ensure the destination lives up to its image and help provide tourists with a satisfactory experience from their visits. There is no doubt that destination image management is one of the most important aspects of marketing because travellers' images are likely to have a rather strong effect on their decision making and selection behaviour (Chi, 2012).

Tourists' subjective evaluation of a destination, their choice and consequent behaviour tend to be influenced by destination image (e.g., Castro, Armario i Ruiz, 2007; Chi, 2011; Chi, Qu, 2008). Destinations with positive images tend to be selected as those of choice because the positive image influences tourists to assume that the destination's products and services will be of high value as well (Chen, Tsai, 2007; Chi, Qu, 2008) and that will contribute towards their overall satisfaction. This indicates the positive relationships between image and satisfaction, as well as between image and quality. However, it is also suggested that the relationship between image and satisfaction is reciprocal, tourists' actual experiences affect their post-trip subjective evaluations as well as their image of the destination (Chi, 2012). Studies also suggest that there may be a direct relationship between destination image and perceived value (Mahasuweerachai, Qu, 2011). However, previous work that examined this relationship reported contradictory results. For example, Andreassen \& Lindestad (1998) contend that while image is likely to have significant impact on other outcome variables, such as perceived quality and satisfaction, there was no significant relationship reported between image and value. Their findings suggested that the impact of image on value was moderated by perceived quality.

There is a general consensus that destination image also affects the behavioural intentions of tourists (Castro, Amario, Riuz, 2007; Chen, Gursoy, 2001; Chen, Tsai, 2007). For example, Mahasuweerachai \& Qu (2011) found that the image positively affects visitors' intentions to revisit in the future. Further, Andreassen \& Lindestad (1998) suggest that image tends to have significant impact on customer satisfaction, quality, and loyalty in a service context. On the other hand, Castro et al. (2007) found that the influence on loyalty of a destination's image is likely to be moderated by service quality and/ or tourist satisfaction. Chen \& Tsai (2007) also support the notion that destination image is likely to have the most important effect on behavioural intentions (i.e. intention to revisit and willingness to recommend). Based on the preceding discussion, this work proposes that destination image is likely to have significant impact on quality, satisfaction, and destination loyalty.

Hypothesis one: Ecotourists' destination images can influence their ecotourism destination loyalty

\section{DESTINATION KNOWLEDGE/ FAMILIARITY}

Destination knowledge can be described as all destination-related information stored in a traveller's mind (Gursoy, 2011a) especially in their long-term memory (Gursoy, McCleary, 2004a, 2004b). Knowledgeable consumers will use their prior product knowledge or information to facilitate their decision making more effectively (Gursoy, 2011a). The process starts with retrieval of information from long-term memory (Ramkissoon, Nunkoo, 2008) to evaluate something in terms of utility, attributes, and applications (Ratchford, 2001). Prior product knowledge enhances a consumer's internal memory and facilitates the decision-making process (Gursoy, 2011b). It also influences the nature of information search and storage in long-term memory (Gursoy, 2011a). According to Gursoy \& Gavcar (2003), consumers tend to acquire information to reduce expected risk within an uncertain situation (Gursoy, 2003) and to reduce the discrepancy between external information and prior knowledge to protect themselves and maximize their satisfaction (Gursoy, McCleary, 2004b). Ramkissoon \& Nunkoo, (2008) have broadly defined knowledge as brand awareness, attributes, benefits, images, thoughts, feelings, attitudes and experiences. In the context of ecotourism, the knowledge that a potential ecotourist has about a destination has been found to influence its choice (Ezebilo, 2014).

Alba \& Hutchinson (1987) suggest that a consumer's knowledge is likely to have two dimensions: 1 . Familiarity - the amount of exposure to the product through past purchases, past use, indirect experiences, on-going participation and learning; and 2. Expertise - the ability to perform product-related tasks. Familiarity reflects the initial stages of learning and expertise reflects the more advanced phases of learning. Alba \& Hutchinson, (1987) suggest that increased familiarity with a product increases expertise about the product as well. On the other hand, Keller (2003) suggests that knowledge is the basis and precursor of brand equity or "the sum of factors (or dimensions) contributing to a brand's value in the consumer's mind" (Konecnik, Gartner, 2007, p. 401). Keller $(1993,1998)$ also suggests that brand knowledge potentially has two major components: brand 
awareness and brand image. Brand awareness is akin to Alba \& Hutchinson's (1987) familiarity construct. In this study, destination knowledge is to have two components: destination familiarity/ awareness and expertise. Destination familiarity/ awareness refers to "what someone knows or thinks they know about a destination" (Konecnik, Gartner, 2007, p. 403) which is likely to influence image and loyalty.

Hypothesis two: Ecotourists' destination knowledge can influence their destination loyalty

\section{INFORMATION SEARCH BEHAVIOUR}

There is a consensus that destination selection and onsite trip decisions begin with information search (Chen, Gursoy, 2000; Gursoy, 2011a; Gursoy, McCleary, 2004a, 2004b; Ramkissoon i Nunkoo, 2008). Information search behaviour is defined by Engel, Blackwell \& Miniard, (1995) as the wilful initiation of knowledge inside the memory or the retrieval of data from the surroundings. This means that information search can take place internally or externally (Engel, Blackwell, Miniard, 1995).

Information search is triggered whenever travellers need to make a decision, and is often started internally i.e. from a memory of past experience (Gursoy, 2011b). Internal information refers to first hand experiences about a destination or one that is similar to it, and cumulative knowledge (Fodness, Murray, 1997). If internal search proves sufficient to help decision-making, then an external search becomes unneeded (Gursoy, McCleary, 2004b). However, in cases where internal sources are incomplete or insufficient, then tourists would seek external supplementary information. Gursoy, (2011b) contends that travel decisions often require supplementary information from external sources to ensure a good final decision.

According to Fodness \& Murray (1997), external information search has been conceptualized in the literature in terms of degree and direction. How much external information is gathered depends on the number of sources used and the amount of time devoted to the search (Gursoy, 2011a). The intensity of pre-purchase external information searching depends on the type of product in question. The higher the price, visibility and complexity of the product, the more the perceived risk and the more information searching required (Ramkissoon, Nunkoo, 2008). Researchers such as Fodness \& Murray (1997), Chen \& Gursoy (2000) and Ramkissoon \& Nunkoo (2008) contend that travellers to international and new destinations have a tendency to use external information searching. However, not much is yet known on the influence of information search behaviour on ecotourists' levels of knowledge, destination image, perception of quality and loyalty.

Hypothesis three: Ecotourists' information search behaviour can influence their destination loyalty

\section{INVOLVEMENT}

The concept of involvement has been widely utilized in the consumer literature particularly on leisure, recreation and tourism (Dimanche, Havitz, Howard, 1993; Gursoy, Gavcar, 2003). It refers to "personal relevance" (Zaichkowsky, 1985) or a consumer's level of participation in relation to an object, situation or action. Personal relevance to a product is represented by a perceived linkage between needs, goals and values, and product knowledge. A consumer's feelings of personal relevance or involvement with a product depend on the extent that product characteristics are associated with personal goals and values (Chen, Li, Chen, 2013).

When an individual is highly involved in decision making, he/ she will invest time and resources to identify the problem, search for more information, and evaluate available options before making a purchase (Gursoy, Gavcar, 2003). Consumers who are highly involved are likely to use more criteria to search for more information. They will use more external information sources, evaluate fewer alternatives, and examine the importance and relevance of the information in detail (Fatima, Razzaque, 2013), produce more product-related thoughts and make more product inferences, want to know the strengths and weaknesses of possible alternatives in more detail, and will form attitudes that are more resistant to change. Not much is yet known about the influence of involvement on a consumer's information search behaviour, knowledge, perception of quality, destination image and their loyalty particularly within the context of ecotourism.

Hypothesis four: Ecotourists' level of involvement can influence their destination loyalty

\section{TRAVEL MOTIVATION}

Studies suggest that the motivation of travellers is likely to influence their satisfaction with the destination and therefore have an indirect influence on traveller loyalty (Prebensen, Woo, Chen, Uysal, 2013; Yoon, Uysal, 2005). According to Pizam, Neumman, \& Reichel (1979), tourist motivation refers to an individual's impulse to engage in a tourism activity. It is the consequence of internal and external drivers (Gursoy, 2011b; Prebensen, Woo, Chen, Uysal, 2013) and is often an initiator to a traveller's 
purchase decision (Chi, 2011). Knowing the reasons why a destination is chosen is important for tourism marketeers (Lee, Hsu, 2013) because it helps them understand travel motivation and factors influencing a destination choice. As one of the most frequently studied topics in the field of hospitality and tourism, theories developed in other fields such as Maslow's Hierarchy of Needs (Maslow, 1943) and Murray's (1938) classification of human needs have been used to study why people travel. This then evolved into a call for the development of travel motivation theories by Lundberg in 1971 and Dann in 1981. Consequently, numerous theories have since emerged including social psychological (Iso-Ahola, 1982), content (Witt, Wright, 1992), and expectancy (Witt, Wright, 1992).

In examining the tourist motivation literature, it is clear that there are four main approaches, each of which can be linked back to earlier motivation theories in the consumer behaviour literature (Prebensen, Woo, Chen, Uysal, 2013). These include the work of Maslow (1943) which can be linked to needs-based theory, the work of Rokeach (1968) which can be linked to value-based theories, expectancy theory (e.g., Witt, Wright, 1992) and benefits-sought theory (e.g. Frochot, Morrison, 2000; Pearce, Caltabiano, 1983). Iso-Ahola (1982) proposes that tourism and recreation are motivated by a seeking for personal and interpersonal escapes.

According to Gavcar \& Gursoy (2002), push-pull theory has been one of the most frequently used to understand why people travel because it studies travel motivations from a two-dimensional perspective i.e. the assumption that travel choices are influenced by either their desires (push factor) or by being attracted to specific destination attributes (pull) (Prebensen, Woo, Chen, Uysal, 2013). While internal forces such as the desire to escape from routine, relax or seek entertainment are related to tourist wishes, pull motivations such as a beautiful environment and cheap prices are related destination attributes (Prebensen, Woo, Chen, Uysal, 2013). Push factors are mostly intangible needs inside an individual traveller (Gavcar, Gursoy, 2002) or socio-psychological, socioeconomic and demographic variables, as well as the 'Attitudes, Interests and Opinions' (AIO) of travellers (Prebensen, Woo, Chen, Uysal, 2013). In contrast, destination specific factors are the pull factors that could influence travellers' destination choice (Prebensen, Woo, Chen, Uysal, 2013) and are either tangible or intangible destination attributes (Lee, Hsu, 2013). To be effective, pull factors must be perceived and valued by the travellers (Yoon, Uysal, 2005).

Kasim, Gursoy, Chi \& Sreenivasan (2014) have proposed that ecotourists are essentially different from regular tourists, particularly in relation to what could influence their travel motivation and trip satisfaction. Ecotourists' travel motivation focuses include environmental and adventure-based motivations (Fennell,
1990; Kretchman, Eagles, 1990; Williacy, Eagles, 1990; Eagles, 1992) covering aspects such as learning about nature, understanding local culture, taking photos of unique and scenic areas or objects and outdoor sightseeing (Eagles, 1992). What motivates ecotourists, according to Crossley \& Lee (1994) and Wight (1996), are preferences for 1) quieter locations, 2) isolated areas of wilderness, 3) wildlife education, 4) the physical environment, 5) community benefit, 6) viewing plans and animals, and 7) physical challenge. A study by Eagles \& Cascagnette (1995) for example, has identified 'desire to visit wilderness' as the top-ranked travel motivation for Canadian ecotourists. Bastic \& Gojcic (2011) refer to this as 'ecological motivation'. Their study on Slovenian hotels (without an eco-label) and Austrian hotels (with an eco-label) found four factors affecting ecological motivation: bio-food, efficiency of water use and energy, the eco-behaviour of the hotel's staff, and healthy and environmentally-friendly equipment. Their findings showed that guests at Austrian hotels are more loyal compared to those who stay in Slovenian hotels because the former had higher ecological motivation than the latter. In addition, Austrian hotel guests perceived a higher level of service quality which indicates that an eco-label may attract tourists to a higher level of ecological motivation (Bastic, Gojcic, 2011).

Meanwhile, Kasim, Gursoy, Chi \& Sreenivasan's (2014) review of the literature has identified that in understanding motivation in an ecotourism context, most studies have mostly focused on physical motivations. For example, Peruvian Amazon ecotourists look forward to the likelihood of seeing particular species that are unique, such as mega fauna (Okello, Manka, D'Amour, 2008; Naidoo i Adamowicz, 2005; Okello, Wishitemi, Mwinzi, 2001; Walpole, Leader-Williams, 2002). In Africa, ecotourists are driven by the possibility of watching flagship species because they are easily observed due to their large size. Meanwhile, Moscardo \& Woods' (1998) study on ecotourists from Taiwan, Australia and Japan, found a predisposition towards 1) touring water-based nature attractions such as lakes and rivers; 2) engaging in nature-related activities at national parks and ecological sites. Clearly, ecotourists enjoy engaging in physically active lifestyles and new experiences when visiting the ecotourism sites of their choice (Kasim, Gursoy, Chi, Sreenivasan, 2014). In such cases, ecotourist satisfaction is largely built on image and expectations of various experience elements such as destination setting and landscape, opportunity to learn, uniqueness of cultures, an interpretative education program and guides (Bowen, 1999; Mackoy \& Osland, 2004). On the other hand, ecotourist travel motivation has a social dimension. Eagles (1992) proposes that ecotourists prefer to travel in groups (social motivation) and are motivated by factors that are nature-oriented 
(attraction motivation). Moscardo \& Woods (1998) found that ecotourists also seek social gratifications in terms of nature education, nature photography, activity and lifestyle, a new social circle and adventure while making full use of the limited time they have on a particular trip.

For this study, motivation is operationalized using push factors (under 'relaxation', 'excitement', 'pleasure', 'socialization', 'bonding', 'culture', 'education/learning', 'nature', 'self actualization' and 'wildlife sighting'). It proposes via the following hypothesis that even in an ecotourism context, the motivation of travellers is likely to have a significant impact on their satisfaction with the destination.

Hypothesis five: Ecotourists' travel motivations can influence their loyalty

\section{METHOD}

The study explores the following relationships: 1 . The influence of ecotourists' travel motivations on their destination loyalty; 2 . The influence of ecotourists destination image on their destination loyalty; 3 . The influence of ecotourists' information search behaviour on their destination loyalty; and 4 . The influence of ecotourists' level of involvement on their destination loyalty. This followed the procedures recommended by Churchill (1979) and DeVellis (1991) in developing its instrument. To develop the item pool, the first step involved a review of the literature and focus group interviews with 1 . travellers to ecotourism areas of Malaysia (10 people) and 2. industry professionals (4). Issues on content validity of the items, clarity, readability, and content validity were resolved at this stage. Targeting international ecotourists as respondents, the next step involves translating the instrument back to back from English to Mandarin to ensure that Mandarin speaking tourists were not excluded from the study. Mandarin was given priority to cater for the increase of Chinese tourists in Malaysia. Translation to other languages was not conducted due to lack of resources and language experts. Hence the strategy was to approach only English and Mandarin-speaking international ecotourists.

The instrument was pre-tested, revised accordingly and finalized based on the pre-test results. The study was conducted on-site using a self-administered survey approach in important ecotourism destinations i.e. 1) both marine and terrestrial in Sabah (Mt. Kinabalu, Crocker Range and Tawau Hills, Turtle Island, Tunku Abdul Rahman and Pulau Tiga); 2) Taman Negara Pahang; 3) Belum National Park; and 4) Penang National Park. These four constitute the primary ecotourism destinations in Malaysia. Using information on the population of international visitors from these sites, a target sample of 1721 was determined (95\% accuracy at confidence interval of \pm 4 ). The outcome was a total of 813 samples, giving the study a response rate of $47 \%$, a number considered sufficient for the purpose of the analysis because for a structural equation modelling (SEM), approximately only 200 responses are required to fulfil the assumptions and parameters of a survey project (Bennekom, 2000). Wolf, Harrington, Clark \& Miller (2013) propose that the sample size for SEM should ideally be from 30 (for Simple CFA with four indicators and loadings of around 0.80 ) to 450 cases (for mediation models).

The sample was randomly selected and divided into two sub-samples. An exploratory factor analysis (EFA) with a principal component method with varimax rotation was performed to detect scale dimensionality on the first sub-sample (from now on referred as Sample One). The Kaiser-Meyer-Olkin measure of sampling adequacy (with a value of 0.60 or above) and a significant Bartletts test of sphericity (Tabachnick, Fidel 1989) were used to detect the appropriateness of factor analysis. Attributes that had factor loadings of lower than 0.40 and attribute loading on more than one factor, with a loading score of equal to or greater than 0.40 on each factor, were eliminated from the analysis to ensure that each factor identified by EFA has only one dimension and that each attribute was loaded on only one factor (see Hattie 1985). This is followed by a Cronbach's Alpha reliability test to evaluate the reliability of each measurement scale using the first sub-sample (Zaichkowsky, 1985). Lastly, a confirmatory factor analysis was performed on the second subsample followed by an examination of chi-square (c2) statistics and associated $P$ values to determine the fit of the measurement model. Jöreskog (1993) contends that the test is the most objective method of testing the fit of a confirmatory model. However, there are also other fit indices often utilized because of the problems associated with the test (Hu, Bentler 1995). The theoretical model that examines ecotourists' destination loyalty to Malaysian ecotourism destinations, and the factors that are likely to influence it was tested using the Structural Equation Model (SEM) approach. SEM enables the testing of multiple equations with multiple dependent variables to provide parameter values (i.e. path coefficients) for each of the research hypotheses and determines their respective significance.

\section{RESULTS AND DISCUSSION}

A total of 813 international tourists participated in this study. Table 1 shows the detailed of descriptive statistics of the respondents' demography. 
Table 1. Background of the respondents

\begin{tabular}{|c|c|c|}
\hline & Frequency & Percentage \\
\hline \multicolumn{3}{|c|}{ Purpose of the trip } \\
\hline Business & 108 & 13.3 \\
\hline Shopping & 288 & 35.4 \\
\hline Pleasure in any setting & 87 & 10.7 \\
\hline Relaxation in natural setting & 226 & 27.8 \\
\hline Learning about local nature and culture & 104 & 12.8 \\
\hline \multicolumn{3}{|c|}{ Number of ecotourism sites visited } \\
\hline One site & 670 & 82.4 \\
\hline $2-5$ sites & 129 & 15.9 \\
\hline 6-10 sites & 10 & 1.2 \\
\hline $11-15$ sites & 4 & 0.5 \\
\hline \multicolumn{3}{|c|}{ Gender } \\
\hline Male & 409 & 60.1 \\
\hline Female & 271 & 39.9 \\
\hline \multicolumn{3}{|c|}{ Age (years) } \\
\hline $18-25$ & 13 & 1.6 \\
\hline $26-33$ & 177 & 21.8 \\
\hline $34-41$ & 446 & 54.9 \\
\hline $42-49$ & 146 & 18.0 \\
\hline$\geq 50$ & 31 & 3.8 \\
\hline \multicolumn{3}{|c|}{ Marital status } \\
\hline Single & 334 & 49.1 \\
\hline Married & 333 & 49.0 \\
\hline Other & 13 & 1.9 \\
\hline \multicolumn{3}{|c|}{ Employment } \\
\hline Students & 145 & 27.4 \\
\hline Professional & 93 & 17.5 \\
\hline Business & 194 & 36.6 \\
\hline Other & 98 & 18.5 \\
\hline \multicolumn{3}{|c|}{ Origin } \\
\hline Asia & 180 & 35.4 \\
\hline Africa & 38 & 7.5 \\
\hline Europe & 114 & 22.4 \\
\hline North America & 24 & 4.7 \\
\hline South America & 48 & 9.4 \\
\hline Oceania & 104 & 20.5 \\
\hline \multicolumn{3}{|c|}{ Travelling } \\
\hline Alone & 96 & 18.1 \\
\hline With friend & 191 & 36.1 \\
\hline With colleagues & 50 & 9.5 \\
\hline With family & 140 & 26.5 \\
\hline Other & 52 & 9.8 \\
\hline \multicolumn{3}{|c|}{ Number of previous trips to this destination } \\
\hline None & 192 & 41.6 \\
\hline Once & 125 & 27.1 \\
\hline Twice & 94 & 20.4 \\
\hline More than twice & 50 & 10.8 \\
\hline
\end{tabular}


Table 1. (cont.)

\begin{tabular}{|c|c|c|}
\hline & \multirow{2}{*}{ Frequency } & \multirow{2}{*}{ Percentage } \\
\hline & & \\
\hline \multicolumn{3}{|c|}{ Type of accommodation } \\
\hline Hotel & 292 & 57.6 \\
\hline Motel & 71 & 14.0 \\
\hline Guesthouse & 75 & 14.8 \\
\hline Homestay & 69 & 13.6 \\
\hline \multicolumn{3}{|c|}{ Length of stay } \\
\hline Less than 3 days & 260 & 49.1 \\
\hline 4 days to a week & 198 & 37.4 \\
\hline 8 days to 2 weeks & 37 & 7.0 \\
\hline More than 14 days & 34 & 6.4 \\
\hline \multicolumn{3}{|c|}{ Been in Malaysia before? } \\
\hline Yes & 388 & 80.2 \\
\hline No & 96 & 19.8 \\
\hline \multicolumn{3}{|c|}{ Plan to revisit } \\
\hline Yes & 427 & 84.9 \\
\hline \multicolumn{3}{|c|}{ Plan to volunteer on the next visit } \\
\hline Yes & 287 & 54.2 \\
\hline \multicolumn{3}{|c|}{ Plan to make a donation } \\
\hline Yes & 259 & 48.9 \\
\hline
\end{tabular}

Source: authors.

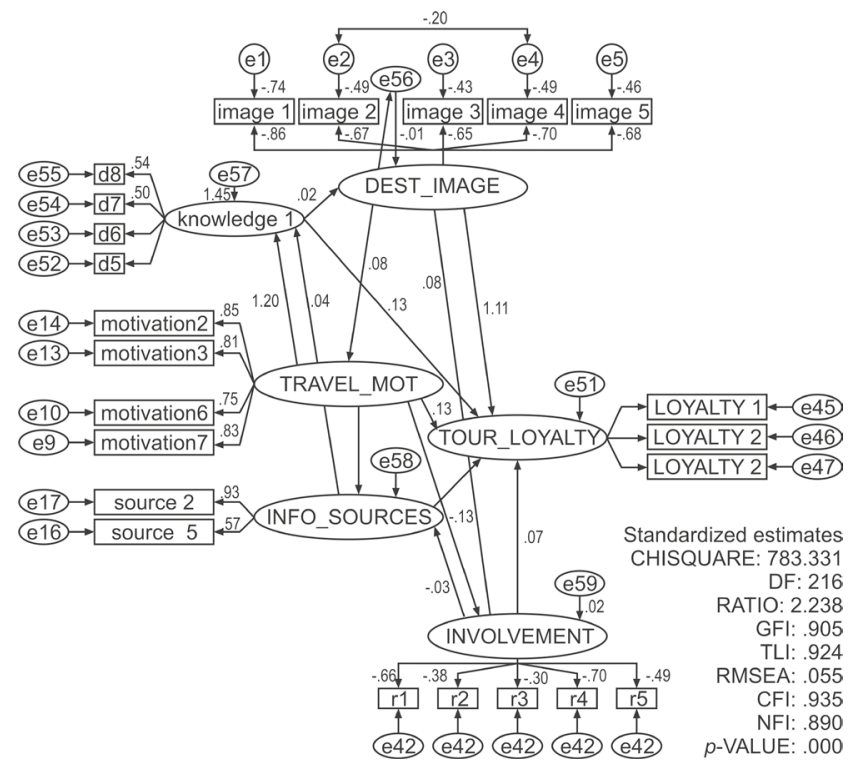

Figure 1. Structural equation modelling of tourist destination loyalty

Source: authors

Coefficient alphas for all study variables were above the acceptable level of 0.60 (Cavana, Delahaye, Sekaran, 2001) ranging from a minimum of 0.701 to 0.802 . Accordingly, no items were deleted from the presented scales. All the variables in this study have values above 0.60. In addition, the SEM model fit results indicated a good model fit for the sample data since most of the indices
Table 2. Goodness-of-fit results of second order confirmatory factor analysis model

\begin{tabular}{|l|c|}
\hline \multicolumn{1}{|c|}{ Goodness-of-fit indices } & Value \\
\hline Chi-square $\left(\chi^{2}\right)$ & 483.331 \\
\hline Degree of Freedom $(d f)$ & 216 \\
\hline Normed Chi Square $\left(\chi^{2} / d f\right)$ & 2.238 \\
\hline Goodness-of-Fit Index $(\mathrm{GFI})$ & 0.905 \\
\hline Comparative Fit Index (CFI) & 0.935 \\
\hline Tucker-Lewis Index (TLI) & 0.924 \\
\hline Root Mean Square Error of Approximation (RMSEA) & 0.055 \\
\hline Sig. $(p)$ & 0.000 \\
\hline
\end{tabular}

Source: authors.

sufficiently fulfilled their relative recommended thresholds. Reasonable rules of thumb as suggested by many researchers are greater than 0.9 for Normed Fit (NFI), Tucker-Lewis (TLI), Comparative Fit (CFI) and Goodness fit (GFI) indices. Meanwhile MacCallum, Browne and Sugawara (1996) have used 0.01, 0.05, and 0.08 to indicate excellent, good, and moderate fit, respectively. As exhibited in Figure 1, all of the fit index values were more than satisfactory, except for NFI (NFI $=0.890)$. However, Kenny \& McCoach (2003) suggested that this measurement is not recommended as it affected by the number of parameters. Hence, the proposed model is assumed to have achieved good fit indices. 


\section{HYPOTHESES TESTING}

Five major hypotheses were developed to be tested by the Structural Model. The results of variance estimation of CFA are summarised in Table 3. Results indicated that the overall structural model explained 45 percent of Destination Loyalty Formation $\left(\mathrm{R}^{2}=0.45\right)$. The path analysis showed only three latent variables: Destination Image $(B=0.17, C R=2.549, p<0.05)$, Level of Destination Knowledge/familiarity $(B=0.17, C R=3.527, p<0.01)$ and Travel Motivation $(B=0.32, C R=4.678, p<0.01)$. Thus, the results of CFA have successfully supported only $\mathrm{H} 1$, $\mathrm{H} 2$ and H5 (Table 4).

Table 3. Regression weight of the structural model

\begin{tabular}{|l|l|c|c|c|}
\cline { 2 - 5 } \multicolumn{1}{c|}{} & \multicolumn{1}{c|}{ Variables } & Estimate & CR & Sig. \\
\hline \multirow{3}{*}{$\begin{array}{l}\text { Loyalty } \\
\left(\mathrm{R}^{2}=0.45\right)\end{array}$} & $\begin{array}{l}\text { Destination image (H1) } \\
\text { Destination knowledge/ } \\
\text { familiarity (H2) }\end{array}$ & 0.168 & 2.459 & 0.014 \\
\cline { 2 - 5 } & $\begin{array}{l}\text { Information search } \\
\text { behaviour (H3) }\end{array}$ & 0.174 & 3.257 & 0.001 \\
\cline { 2 - 5 } & $\begin{array}{l}\text { Level of involvement } \\
\text { (H4) }\end{array}$ & 0.094 & 1.601 & 0.109 \\
\cline { 2 - 5 } & Travel motivation (H5) & 0.320 & 4.678 & 0.000 \\
\hline
\end{tabular}

Source: authors.

Table 4. Hypothesis testing results

\begin{tabular}{|c|c|}
\hline \multicolumn{1}{|c|}{ Hypotheses } & Results \\
\hline $\begin{array}{c}\text { H1: Ecotourists' destination image can } \\
\text { influence their ecotourism destination } \\
\text { loyalty. }\end{array}$ & Supported \\
\hline $\begin{array}{c}\text { H2: Ecotourists' destination knowledge } \\
\text { can influence their destination loyalty. }\end{array}$ & Supported \\
\hline $\begin{array}{c}\text { H3: Ecotourists' information search be- } \\
\text { haviour can influence their destination } \\
\text { loyalty. }\end{array}$ & Not supported \\
\hline $\begin{array}{c}\text { H4: Ecotourists' level of involvement can } \\
\text { influence their destination loyalty }\end{array}$ & Not Supported \\
\hline $\begin{array}{c}\text { H5: Ecotourists' travel motivations can } \\
\text { influence their loyalty. }\end{array}$ & Supported \\
\hline
\end{tabular}

Source: authors.

\section{DISCUSSION}

This study admittedly offers little theoretical contribution as it could not find any support for contentions on the relationships between destination loyalty with travel motivations, image, information search, and involvement as found in past studies (for example Castro, Armario, Ruiz, 2007; Chen, Gursoy, 2001; Chen, Tsai,
2007; Chi, 2011; Chi, Qu, 2008; Gursoy, Gavcar, 2003; Gursoy, McCleary, 2004a, 2004b; Havitz, Dimanche, 1999; Konecnik, Gartner, 2007; Yoon, Uysal, 2005). On the other hand, it does offer some managerial implications that could be used by destination marketing managers working in a similar context. For example, it found that ecotourists' level of involvement can influence their destination image. The managerial implication of this is that destination managers must formulate various interesting and meaningful activities that ecotourists could engage in during their visit so they could perceive better image of the destination which could influence their future travel decision. This is because past studies have found that a positive destination image can influence a tourist's visit decision ( $\mathrm{O}^{\prime}$ Leary, Deegan, 2005) and that a positive and favourable one is likely to influence their desire to visit the destination (Laws, Scott, Parfitt, 2002). In short, active involvement of ecotourists in their first visit can influence their destination image. Destination managers need to make ecotourists feel involved during their stay to the extent that the destination characteristics are linked with ecotourists' personal values and goals (Chen, Li, Chen, 2013) so that they will feel that the destination has "personal relevance" (Zaichkowsky, 1985) to them. If this is achieved, ecotourists' positive experience will likely lead to positive destination image and influence their future decisions to revisit.

Another managerial implication that could be drawn from the finding is that there is a positive relationship between ecotourists' information search behaviour and their level of familiarity or knowledge about a destination. Perhaps oversea ecotourism destinations are perceived as a complex product with greater risk that make people engage in more searches (Ramkissoon, Nunkoo, 2008). If this were true, then ecotourists are more likely to utilize external information search (Chen, Gursoy, 2000; Fodness, Murray, 1998; Ramkissoon, Nunkoo, 2008). One managerial implication of this is evident: destination managers should leverage on ecotourists' information search behaviour by presenting interesting, positive images. Since tourists are often pulled by destination attributes that are expected to provide them satisfaction (Prebensen, Woo, Chen, Uysal, 2013), enhanced destination knowledge will contribute towards a future motivation to visit.

Finally, the finding that there is a significant relationship between ecotourists' motivations and their involvement implies that destination managers must develop strategies that could enhance both push and pull factors (Gavcar, Gursoy, 2002) and influence travel motivations. While the push factors may not be so easy to manipulate, destination managers/marketeers can still try to ensure that the destination attributes (pull factors) are positively perceived and valued by travellers (Yoon, Uysal, 2005). They need to make ecotourists 
feel more involved because being involved means feeling that a destination has personal relevance to one's own goals and values. This feeling is important to cultivate because it could influence information processing and decision making (Fatima, Razzaque, 2013) which can lead to positive destination image.

\section{CONCLUSIONS}

In conclusion, this study has attempted to look at the influence of several destination loyalty antecedents simultaneously with the intention to see the bigger picture as not many past studies have focused on a combination and offers new information for destination managers on how to manage destination loyalty within their work context. Hence the findings have industrial relevance and could be found useful by destination managers.

Admittedly this study has many limitations that can and should be addressed by future researchers who should try to replicate the study to find linear relationships between the selected antecedents and destination loyalty within their respective study contexts by perfecting the sampling strategies to get better or bigger sample to enable better analyses. In addition, they could engage in a qualitative or mixed-method approach to get more meaningful results. A mixed method approach for this study could help answer not only the 'what' questions but also the 'why' questions to enhance understanding on the issue. In addition, future studies should focus on both domestic and international ecotourists to see if differences exist between them. Finally, it is recommended that future studies use a longitudinal approach to generate results that could be better than the cross-sectional one that this study offers.

\section{ENDNOTE}

\footnotetext{
${ }^{1}$ This project was made possible by Fundamental Research Grant Scheme (FRGS, code SO 12946) awarded by the Ministry of Higher Education Malaysia.
}

\section{REFERENCES}

Alba, J., Hutchinson, J. (1987). Dimensions of consumer expertise. Journal of Consumer Research, 13, 411-453. DOI: https://doi. org/10.1086/209080

Andreassen, T.W., Lindestad, B. (1998). Customer loyalty and complex services. International Journal of Service Industry Management, 91, 7-23. DOI: https://doi.org/10.1108/09564239810199923

Baloglu, S., McCleary, K.W. (1999). US international pleasure travelers' images of four Mediterranean destinations: A compa- rison of visitors and nonvisitors. Journal of Travel Research, 38 (2), 144-152. DOI: https://doi.org/10.1177/004728759903800207

Bastic, M., Gojcic, S. (2011). The ecological motivation of tourists as a determinant of the tourists' loyalty. Croatian Operational Research Review, 2, 14-22. DOI: https://doi.org/10.1016/ S0262-1762(11)70238-3

Beerli, A., Martin, J.D. (2004). Tourists' characteristics and the perceived image of tourist destinations: A quantitative analysis - a case study of Lanzarote, Spain. Tourism Management, 25 (4), 623-636. DOI: https://doi.org/10.1016/j.tourman.2003.06.004

Bennekom, F.V. (2000). Statistical confidence in survey. Retrieved from: http://www.greatbrook.com/survey_statistical_confidence.htm (7.07.2020).

Blamey, R. (2001). Principles of ecotourism. In: D.B. Weaver (ed.), The encyclopaedia of ecotourism (pp. 5-22). Wallingford, UK: CABI Publishing. DOI: https://doi.org/10.1079/9780851993683.0005

Blamey, R.K., Braithwaite, V.A. (1997). Ecotourism: The search for an operational definition. Journal of Sustainable Tourism, 5, 109-130. DOI: https://doi.org/10.1080/09669589708667280

Bowen, D. (1999). Antecedents of consumer satisfaction and dissatisfaction $(\mathrm{CS} / \mathrm{D})$ on long-haul inclusive tours - a reality check on theoretical considerations. Tourism Management, 22, 49-61. DOI: https://doi.org/10.1016/S0261-5177(00)00022-4

Castro, C.B., Armario, E.M., Ruiz, D.M. (2007). The influence of market heterogeneity on the relationship between a destination's image and tourists' future behaviour. Tourism Management, 28, 175-187. DOI: https://doi.org/10.1016/j.tourman.2005.11.013

Cavana, R., Delahaye, B., Sekaran, U. (2001). Applied business research: Qualitative and quantitative methods. $3^{\text {rd }}$ edition. Australia: John Wiley \& Sons.

Chen, C.F., Tsai, D. (2007). How destination image and evaluative factors affect behavioural intentions? Tourism Management, 28 (4), 1115-1122. DOI: https://doi.org/10.1016/j.tourman.2006.07.007

Chen, J., Gursoy, D. (2000). Cross-cultural comparison of the information sources used by first-time and repeat travellers and its marketing implications. International Journal of Hospitality Management, 19, 191-203. DOI: https://doi.org/10.1016/ S0278-4319(00)00013-X

Chen, J., Gursoy, D. (2001). An investigation of tourists' destination loyalty and preferences. International Journal of Contemporary Hospitality Management, 13, 79-85. DOI: https:// doi.org/10.1108/09596110110381870

Chen, Y.C., Li, R.H., Chen, S.H. (2013). Relationships among adolescents' leisure motivation, leisure involvement, and leisure satisfaction: A structural equation model. Social Indicators Research, 110 (3), 1187-1199. DOI: https://doi.org/10.1007/ s11205-011-9979-2

Chi, C.G. (2011). Destination loyalty formation and travellers' demographic characteristics: A multiple group analysis approach. Journal of Hospitality and Tourism Research, 35 (2), 191-212. DOI: https://doi.org/10.1177/1096348010382233

Chi, C.G. (2012). An examination of destination loyalty: Differences between first time and repeat visitors. Journal of Hospitality and Tourism Research, 36 (1), 3-24. DOI: https://doi. org/10.1177/1096348010382235

Chi, C.G., Qu, H. (2008). Examining the structural relationships of destination image, tourist satisfaction and destination loyalty: An integrated approach. Tourism Management, 29 (4), 624-636. DOI: https://doi.org/10.1016/j.tourman.2007.06.007

Churchill, G.A. Jr. (1979). A paradigm for developing better measures of marketing constructs. Journal of Marketing Research, 16 (1), 64-73. DOI: https://doi.org/10.1177/002224377901600110

Cole, S.T., Illum, S.F. (2006). Examining the mediating role of festival visitors' satisfaction in the relationship between service quality and behavioural intentions. Journal of Vacation Marketing, 12 (2), 160-173. DOI: https://doi.org/10.1177/1356766706062156 
Crompton, J.L. (1979) Motivations for pleasure vacation. Annals of Tourism Research, 6 (4): 408-424. DOI: https://doi. org/10.1016/0160-7383(79)90004-5

Crossley, J., Lee, B. (1994). Ecotourists and mass tourists: A difference in 'benefits sought". 25 $5^{\text {th }}$ Annual Conference, University of Utah Travel and Tourism Research Association Proceedings. October, pp. 22-30.

Dann, G.M. (1981). Tourism motivations: An appraisal. Annals of Tourism Research, 8, 189-219. DOI: https://doi. org/10.1016/0160-7383(81)90082-7

DeVellis, R.F. (1991). Scale development: Theory and applications. Newbury Park, CA: Sage Publications.

Dimanche, F., Havitz, M.E., Howard, D.R. (1993). Consumer involvement profiles as a tourism segmentation tool. Journal of Travel and Tourism Marketing, 14, 33-52. DOI: https://doi. org/10.1300/J073v01n04_03

Donohoe, H., Needham, R.D. (2005). The movement towards national standards: The evolving tenets of ecotourism. LondonOntario: Canadian Association of Geographers Congress.

Dowling, R., Fennell, D. (2003) The context of ecotourism policy and planning. In: D.A. Fennell, R.K. Dowling (eds), Ecotourism Policy and Planning (pp. 1-20). Oxon: CABI Publishing. DOI: https://doi.org/10.1079/9780851996097.0001

Eagel, F.J., Blackwell, R.D., Miniard, P.W. (1995). Consumer behaviour. $8^{\text {th }}$ edition. New York: Dryder.

Eagles, P.F.J. (1992). The travel motivations of Canadian ecotourists. Journal of Travel Research. 31 (2), 3-7. DOI: https://doi. org/10.1177/004728759203100201

Eagles, P.F.J., Cascagnette, J.W. (1995). Canadian ecotourists. Tourism Recreation Research, 20 (1), 22-28, DOI: https://doi.org /10.1080/02508281.1995.11014729

Ezebilo, E.E. (2014). Choosing ecotourism destination for vacations: A decision making process. Asian Social Science, 10 (2), 10-17. DOI: https://doi.org/10.5539/ass.v10n2p10

Fatima, J.K., Razzaque, M.A. (2013). Roles of customer involvement in rapport and satisfaction. Asia Pacific Journal of Marketing and Logistics, 25 (3), 452-471. DOI: https://doi.org/10.1108/ APJML-09-2012-0092

Fennell, D.A. (1990). A profile of ecotourists and the benefits derived from their experience: A Costa Rican case study. Master thesis. Waterloo, Ontario: Department of Recreation and Leisure Studies, University of Waterloo.

Fodness, D., Murray, B. (1997). Tourist information search. Annals of Tourism Research, 24, 503-523. DOI: https://doi.org/10.1016/ S0160-7383(97)00009-1

Frochot, I., Morrison, A. (2000). Benefit segmentation: A review of its applications to travel and tourism research. Journal of Travel and Tourism Marketing, 94, 21-45. DOI: https://doi.org/10.1300/ J073v09n04_02

Gavcar, E., Gursoy, D. (2002). An examination of destinationoriginated (pull) factors. Tourism Analysis, 7 (1), 75-81. DOI: https://doi.org/10.3727/108354202129687705

Gursoy, D. (2003). Prior product knowledge and its influence on the traveller's information search behaviour. Journal of Hospitality and Leisure Marketing, 10 (3/4), 113-131. DOI: https:// doi.org/10.1300/J150v10n03_07

Gursoy, D. (2011a). Modelling tourist information search behaviour: A structural modelling approach. Saarbrücken: Lambert Academic Publishing.

Gursoy, D. (2011b). Chapter 5: Destination information search strategies. In: Y. Wang, A. Pizam (eds). Destination marketing and management. Wallingford: CABI.

Gursoy, D., Gavcar, E. (2003). International leisure tourist's involvement profile. Annals of Tourism Research, 30 (4), 906-926. DOI: https://doi.org/10.1016/S0160-7383(03)00059-8
Gursoy, D., McCleary, K.W. (2004a). An integrative model of tourists' information search behaviour. Annals of Tourism Research, 31 (2), 353-373. DOI: https://doi.org/10.1016/j.annals.2003.12.004

Gursoy, D., McCleary, K.W. (2004b). Travellers' prior knowledge and its impact on their information search behaviour. Journal of Hospitality and Tourism Research, 28 (1), 66-94. DOI: https:// doi.org/10.1177/1096348003261218

Hall, C.M., O'Sullivan, V. (1996). Tourism, political stability and violence. In: A. Pizam, Y. Mansfeld (eds), Tourism crime and international security issues (pp. 105-121). New York: Wiley

Hankinson, G. (2004), The brand images of tourism destinations: A study of the saliency of organic images, Journal of Product \& Brand Management, 13 (1), 6-14. DOI: https://doi. org/10.1108/10610420410523803

Hattie, J. (1985). Methodology review: Assessing uni-dimensionality of tests and items. Applied Psychological Measurement, 9, 139-164. DOI: https://doi.org/10.1177/014662168500900204

Havitz, M., Dimanche, F. (1999). Leisure involvement revisited: Drive properties and paradoxes. Journal of Leisure Research, 31, 122-149. DOI: https://doi.org/10.1080/00222216.1999.11949854

Hawkins, D.E., Lamoureux, K. (2001). Global growth and magnitude of ecotourism. In: D. Weaver (ed.), The encyclopedia of ecotourism (pp. 63-83). New York: CABI Publishing. DOI: https://doi.org/10.1079/9780851993683.0063

Honey, M. (1999). Ecotourism and sustainable development: Who owns paradise? Washington: Island Press.

Honey, M. (2008). Ecotourism and sustainable development, second edition: Who owns paradise? Washington: Island Press.

Hosany, S., Ekinci, Y., Uysal, M. (2007). Destination image and destination personality. International Journal of Culture, Tourism and Hospitality Research, 1 (1), 62-81. DOI: https://doi. org/10.1108/17506180710729619

Hsu, C. (2004). Theory of planned behavior: Potential travelers from China. Journal of Hospitality and Tourism Research, 28 (4), 463-482. DOI: https://doi.org/10.1177/1096348004267515

Hu, L., Bentler, P.M. (1995). Evaluating model fit. In: R. Hoyle (ed.), Structural equation modelling: Concepts: issues and applications (pp. 76-99). Thousand Oaks, CA: Sage.

Hvenegaard, G. (1994). Ecotourism - A status report and conceptual framework. Journal of Tourism Studies, 5 (2), 24-35.

Iso-Ahola, S. (1982). Toward a social psychology theory of tourism motivation. Annals of Tourism Research, 12, 256-262. DOI: https://doi.org/10.1016/0160-7383(82)90049-4

Jamieson, W. (2001). Interpretation and tourism. In: J. Walter (ed.), Community tourism destination management: Principles and practices. Thailand: Saengsawang World Press.

Jöreskog, K.G. (1993). Testing structural equation models. In: K. Bollen, J.S. Long (eds), Testing structural equation models (pp. 294-316). Newbury Park: CA: Sage.

Kamauro, O. (1996). Ecotourism: Suicide or development? Voices from Africa \#6: Sustainable development. UN non-governmental liaison service. United Nations News

Kasim, A., Gursoy, D., Chi, C., Sreenivasan, J. (2014). Measuring ecotourists' destination loyalty. Proceedings of the $3^{\text {rd }}$ Interdisciplinary Tourism Research Conference, 3, 57-64.

Keller, K.L. (2003). Strategic brand management: Building, measuring, and managing brand equity. $2^{\text {nd }}$ edition. Upper Saddle River, New York: Pearson Education, Inc.

Kenny, D.A., McCoach, D.B. (2003). Effect of the number of variables on measures of fit in structural equation modeling. Structural Equation Modeling, 10, 333-351. DOI: https://doi. org/10.1207/S15328007SEM1003_1

Konecnik, M., Gartner, W. (2007). Customer based brand equity for a destination. Annals of Tourism Research, 34 (2), 400-421. DOI: https://doi.org/10.1016/j.annals.2006.10.005 
Kretchman, J.A., Eagles, P.F.J. (1990). An analysis of the Federation of Ontario naturalists' membership trips programme. Ontario: Department of Recreation and Leisure Studies, University of Waterloo.

Laws, E., Scott, N., Parfitt, N. (2002) Synergies in destination image management: A case study and conceptualisation. International Journal of Tourism Research, 4 (1), 39-55. DOI: https://doi.org/10.1002/jtr.353

Lee, C.K., Lee, Y.K., Lee, B. (2005). Korea's destination image formed by the 2002 world cup. Annals of Tourism Research, 32 (4), 839-858. DOI: https://doi.org/10.1016/j.annals.2004.11.006

Lee, T.H., Hsu, F.Y. (2013). Examining how attending motivation and satisfaction affects the loyalty for attendees at aboriginal festivals. International Journal of Tourism Research, 15 (1), 18-34. DOI: https://doi.org/10.1002/jtr.867

Lundberg, D.E. (1971). Why tourists travel. Cornell HRA Quarterly, February, 75-81.DOI: https://doi.org/10.1177/001088047101100413

MacCallum, R.C., Browne, M.W. and Sugawara, H.M. (1996). Power analysis and determination of sample size for covariance structure modeling. Psychological Methods, 1, 130-149. DOI: https://doi.org/10.1037/1082-989X.1.2.130

Mackoy, R.D., Osland, G.E. (2004). Lodge selection and satisfaction: Attributes valued by ecotourists. The Journal of Tourism Studies, 15, 13-25.

Mahasuweerachai, P., Qu, H. (2011). The impact of destination image on value, satisfaction, and loyalty: Moderating effects of tourist characteristics and involvement. $16^{\text {th }}$ Annual Graduate Education and Graduate Student Research Conference in Hospitality and Tourism, Houston, TX, USA

Maslow, A.H. (1943). A theory of human motivation. Psychological Review, 50, 370-396. DOI: https://doi.org/10.1037/h0054346

Mondino, E., Beery, T. (2019). Ecotourism as a learning tool for sustainable development. The case of Monviso Transboundary Biosphere Reserve, Italy. Journal of Ecotourism, 18 (2), 107-121. DOI: https://doi.org/10.1080/14724049.2018.1462371

Moscardo, G., Woods, B. (1998). Managing tourism in the wet tropics world heritage area: Interpretation and the experience of vsitors on Skyrail. In: E. Laws, B. Faulkner, G. Moscardo (eds), Embracing and managing change in tourism: International case studies (pp. 285-306). London: Routledge.

Murray, H.A. (1938). Explorations in personality. New York: Oxford University Press.

Naidoo, R., Adamowicz, W. (2005). Biodiversity and naturebased tourism at forest reserves in Uganda. Environmental and Development Economics, 10, 159-178. DOI: https://doi.org/10.1017/ S1355770X0400186X

Ndubisi, N.O. (2007). Relationship marketing and customer loyalty. Marketing Intelligence and Planning, 25 (1), 98-106. DOI: https:// doi.org/10.1108/02634500710722425

Neal, J.D., Gursoy, D. (2008). Travellers' satisfaction with hospitality and tourism services. Journal of Travel Research, 47 (1), 53-62. DOI: https://doi.org/10.1177/0047287507312434

O'Leary, S., Deegan, J. (2005). Career progression of Irish tourism and hospitality management graduates. International Journal of Contemporary Hospitality Management, 17 (45), 421-432. DOI: https://doi.org/10.1108/09596110510604841

Okello, M.M., Manka, S.G., D'Amour, D.E. (2008). The relative importance of large mammal species for tourism in Ambroseli National Park, Kenya. Tourism Management, 29, 751-760. DOI: https://doi.org/10.1016/j.tourman.2007.08.003

Okello, M.M., Wishitemi, B.E.L., Mwinzi, A.M. (2001). Relative importance of conservation areas in Kenya based on diverse tourist attractions. The Journal of Tourism Studies, 12, 39-49.

Oppermann, M. (2000). Tourism destination loyalty. Journal of Travel Research,39,78-84.DOI:https://doi.org/10.1177/004728750003900110
Palacio, V., McCool, S. (1997). Identifying ecotourists in Belize through benefit segmentation: A preliminary analysis. Journal of Sustainable Tourism, 5 (3), 234-243. DOI: https://doi. org/10.1080/09669589708667288

Pearce, P.L., Caltabiano, M.L. (1983). Inferring travel motivation from travellers' experiences. Journal of Travel Research, 22 (2), 16-20. DOI: https://doi.org/10.1177/004728758302200203

Pizam, A., Neumman, Y., Reichel, A. (1979). Dimensions of tourist satisfaction with a destination area. Annals of Tourism Research, 5 (3), 314-322. DOI: https://doi.org/10.1016/0160-7383(78)90115-9

Plessis, M.L.D., Merwe, P.V.D., Saayman, M. (2012). Environmental factors affecting tourists' experience in South African national parks. African Journal of Business Management, 6 (8), 2911-2918. DOI: https://doi.org/10.5897/AJBM11.1591

Plog, S.C. (1974). Why destination areas rise and fall in popularity. Cornell Hotel and Restaurant Administration Quarterly, 14 (4), 55-58. DOI: https://doi.org/10.1177/001088047401400409

Prayag, G., Ryan, C. (2012). Antecedents of tourists' loyalty to Mauritius: the role and influence of destination. Journal of Travel Research, 51 (3), 342-356. DOI: https://doi. org $/ 10.1177 / 0047287511410321$

Prebensen, N.K., Woo, E., Chen, J.S., Uysal, M. (2013). Motivation and involvement as antecedents of the perceived value of the destination experience. Journal of Travel Research, 52 (2), 253-264. DOI: https://doi.org/10.1177/0047287512461181

Quintal, V.A., Polczynski, P. (2010). Factors influencing tourists' revisit intentions. Asia Pacific Journal of Marketing and Logistics, 22 (4), 554-578. DOI: https://doi. org/10.1108/13555851011090565

Ramkissoon, H., Nunkoo, R. (2008). Information search behaviour of European tourists visiting Mauritius. Turizam: ZnanstvenoStručni Časopis, 56 (1), 7-21.

Ratchford, B. (2001). The economic of consumer knowledge. Journal of Consumer Research, 27, 397-411. DOI: https://doi. org/10.1086/319617

Rokeach, M. (1968). Beliefs, attitudes and values: A theory of organization and change. San Francisco: Jossey-Bass.

Sangpikul, A. (2020). Tourist perceptions of guided ecotourism tours in Thailand. Journal of Ecotourism, 1 (2/3): 104-121. DOI: https://doi.org/10.1177/1467358418824143

Sangpikul,A. (2017). Ecotourism impacts on the economy, society and environment of Thailand. Journal of Reviews on Global Economics, 6, 302-312. DOI: https://doi.org/10.6000/1929-7092.2017.06.30

Sitar, A., May-Collado, L., Wright, A. (2017) Tourists' perspectives on dolphins watching in Bocas Del Toro, Panama. Tourism in Marine Environment, 12 (2), 79-94. DOI: https://doi.org/10.3 727/154427316X14820977775343

Sun, A., Chi, C.G., Xu, H. (2013). Developing destination Loyalty: The case of Hainan Island, China. Annals of Tourism Research, 43, 547-577. DOI: https://doi.org/10.1016/j. annals.2013.04.006

Swarbrooke, J., Horner, S. (1999). Consumer behaviour in tourism. Oxford-Boston: Butterworth-Heinemann.

Tabachnick, B.G., Fidel, F.S. (1989). Using multivariate statistics. Wyd. 2. Nowy Jork: Harper Collins Publishers.

The International Ecotourism Society (TIES) (2006). Fact sheet: Global tcotourism. Retrieved from: www.ecotourism. org/webmodules/webarticlesnet/templates/eco_template. aspx? Articleid=15\&zoneid=2 (25.06.2020).

Uysal, M., Jurowski, C., Noe, F., McDonald, D. (1994). Environmental attitude by trip and visitor characteristics. Tourism Management, 15 (4), 284-294. DOI: https://doi.org/10.1016/0261-5177(94)90046-9

Walpole, M.J., Leader-Williams, N. (2002). Tourism and flagship species in conservation. Biodiversity Conservation, 11, 543-547. DOI: https://doi.org/10.1023/A:1014864708777 
Weaver, D.B. (2005). Mass and urban ecotourism: New manifestations of an old concept. Tourism Recreation Research, 30, 19-26. DOI: https://doi.org/10.1080/02508281.2005.11081230

Wight, P. (1993). Sustainable ecotourism: Balancing economic, environmental and social goals within an ethical framework. Journal of Tourism Studies, 4 (2), 54-66.

Wight, P.A. (1996). North American ecotourists: Market profile and trip characteristics. Journal of Travel Research, 34 (4), 2-10. DOI: https://doi.org/10.1177/004728759603400401

Williacy, S., Eagles, P.F.J. (1990). An analysis of the Federation of Ontario Naturalists' Canadian Nature Tours Programme. Waterloo, Ontario: Department of Recreation and Leisure Studies, University of Waterloo.

Witt, C.A., Wright, P. (1992). Tourist motivation: Life after Maslow. In: P. Johnson, B. Thomas (eds), Choice and demand in tourism (pp. 33-56). London: Mansell.

Wolf, E.J., Harrington, K.M., Clark, S.L., Miller, M.W. (2013). Sample size requirements for structural equation models an evaluation of power, bias, and solution propriety. Educational and Psychological Measurement, 73 (6), 913-934. DOI: https://doi. org $/ 10.1177 / 0013164413495237$

WTTC (2004). World Travel and Tourism Council. Retrieved from: http://www.wttc.org (20.05.2013).

Yoon, Y., Uysal, M. (2005). An examination of the effects of motivation and satisfaction on destination loyalty: A structural model. Tourism Management, 26, 45-56. DOI: https://doi.org/10.1016/j. tourman.2003.08.016

Zaichkowsky, J.L. (1985). Measuring the involvement construct. Journal of Consumer Research, 12, 341-352. DOI: https://doi. org/10.1086/208520

Article received

20 July 2020

Accepted:

21 December 2020 